\title{
Genetic differentiation of oak populations within the Quercus robur/Quercus petraea complex in Central and Eastern Europe
}

\author{
DUŠAN GÖMÖRY*†, IGOR YAKOVLEV‡, PETAR ZHELEV§, JARMILA JEDINÁKOVÁ† \\ \& LADISLAV PAULE† \\ $\dagger$ Faculty of Forestry, Department of Botany, Technical University in Zvolen, Faculty of Forestry, T. G. Masaryka 24, \\ SK-960 53 Zvolen, Slovakia, \$Mari State Technical University, Lenin Place 3, 424000 loshkar-Ola, Russia \\ and §University of Forestry, Faculty of Forestry, Blv. Kliment Ochridski 10, BG-1756 Sofia, Bulgaria
}

\begin{abstract}
Genetic structure of 25 indigenous populations of sessile and pedunculate oaks (Quercus petraea and Q. robur), originating from three geographical regions: Slovakia, Bulgaria and the Republic Mari-El (Russia), was investigated using isozyme markers. Mean number of alleles per locus ranged between 1.8 and 2.6 in $Q$. robur populations and from 2.0 to 3.0 in $Q$. petraea populations; slightly higher expected heterozygosity values were found in $Q$. robur compared to $Q$. petraea. One locus, coding for a substrate-nonspecific dehydrogenase, differentiated the two species. The interspecific component of gene diversity was $46.7 \%$ at this locus, compared to $0.4-7.8 \%$ at the remaining loci.
\end{abstract}

Keywords: differentiation, diversity, isozymes, Quercus petraea, Quercus robur.

\section{Introduction}

The genus Quercus is frequently designated as crux botanicorum among taxonomists. The systematics of this genus is complicated and controversial, and this is reflected in a different number of species recognized by different authors. Linnaeus (1753) proposed 12 species and since then, the number of oak taxa has increased to several hundred; Schwarz (1964) considered 320 taxa to be separate species, plus many forms, varieties or subspecies.

Among the European white oaks (subgenus Lepidobalanus), the species with the highest economic importance and therefore those which have been most intensively studied are Quercus robur L. and Q. petraea (Matt.) Liebl. Several other taxa have been described and found in natural forests over Europe (mainly eastern and southern Europe): $Q$. dalechampii Ten., Q. polycarpa Schur., Q. pedunculiflora C. Koch. In many floras (Greece, Rumania, Serbia, etc., even in Flora Europaea; Schwarz, 1964), these taxa are listed as separate species but there is no general agreement about their taxonomic status among botanists, since great intraspecific morphological variation makes them difficult to distinguish. Thus, they are frequently included in either $Q$. robur or

\footnotetext{
*Correspondence. E-mail: gomory@vsld.tuzvo.sk
}

Q. petraea. Even the taxonomic status of these species sensu lato is an issue of controversy, since they are interfertile (Steinhoff, 1997) and the frequency of individuals with intermediate morphology is high. Some authors even conclude that they should be considered ecotypes or subspecies within one composite species of Q. robur (Kleinschmit et al., 1995; Steinhoff, 1997).

The genetics of European white oaks has been studied extensively by means of isozyme and DNA genetic markers. Almost all studies have had to treat the problem of species identity and patterns of intraspecific and interspecific differentiation. In general, isozyme studies failed to find true species-specific alleles. Alleles that are found in samples of one species but absent in samples of the other, are generally of low frequencies, so that their absence may be due to sampling error. There are, however, significant differences in allelic frequencies between both species at several loci (Müller-Starck \& Ziehe, 1991; Zanetto et al., 1994). Analysis of total proteins using two-dimensional electrophoresis showed similar results; no species-specific spots, but significant differences in the frequency of some protein fractions between both oak species (Barreneche et al., 1996).

Similarly, in most studies, DNA markers do not appear to differentiate the species. Sessile and pedunculate oaks share the same cytoplasmic genes when they occur in the same stand (Petit et al., 1993). It has even been shown that such local sharing applies to at least 
seven oak species of the subgenus Lepidobalanus (Dumolin-Lapègue et al., 1997). No difference between $Q$. robur and $Q$. petraea in the distribution of rDNA length variants was found by Petit et al. (1993). RAPD fragments also failed to discriminate the species (Moreau et al., 1994; Bodénès et al., 1997).

Despite this general lack of differentiation, the existence of interspecific differences has been shown in some studies based on genetic markers. Bordács \& Burg (1997) demonstrated the existence of two species-specific RAPD markers differentiating $Q$. robur (s.l., including ssp. slavonica) from $Q$. petraea (s.l., including Q. dalechampii). Recently, Muir et al. (2000) presented microsatellite marker data that discriminated the two species, thus supporting the view that they represent different taxonomical units.

Most of the cited studies are based on western European populations. Samples from eastern Europe appear regularly, but they are much less well represented, especially samples from the eastern-most part of the oak distribution range (Russia). This study aims to fill this information gap by comparing the genetic structure of Russian oak populations with those from central and south-eastern Europe.

\section{Materials and methods}

Twenty-five indigenous populations (preferably from nature reserves) of sessile and pedunculate oaks were selected in three geographical regions (Fig. 1.): Slovakia (central Europe), Bulgaria (Balkans) and Republic
Mari-El (Russia, near the Volga river, only pedunculate oak). Twigs with dormant buds were taken from 30 to 60 trees in each population. Enzymes were extracted from buds using Tris- $\mathrm{HCl}$ buffer $\mathrm{pH} 7.5$ (Longauer, 1996) and separated by means of starch-gel electrophoresis using three buffer systems (Li-borate/tris-citrate

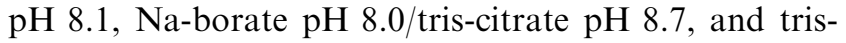
citrate/tris-histidine $\mathrm{pH}$ 7.0). Eight isoenzyme systems were used (E.C. numbers and controlling loci given in parentheses): fluorescent $\alpha$-esterase (E.C. 3.1.1.1; Fest-A), menadione reductase (E.C. 1.6.99.2; $M n r-A$ ), malate dehydrogenase (E.C. 1.1.1.37; $M d h-D$ ), isocitrate dehydrogenase (E.C. 1.1.1.42; Idh-B), shikimate dehydrogenase (E.C. 1.1.1.25; $S k d h-A$ ), glutamate-oxaloacetate transaminase (E.C. 2.6.1.1; Got-B), phosphoglucose isomerase (E.C. 5.3.1.9; Pgi-B), and a nonspecific NADdependent dehydrogenase, able to utilize glucose and sorbitol as a substrate (E.C. 1.1.1.47; Gludh-A). Locus designation conforms with Zanetto et al. (1996) and Müller-Starck et al. (1996), who showed Mendelian inheritance for these systems, except Gludh-A, where the Mendelian inheritance was inferred from the isozyme phenotypes (alternative occurrence of single-banded variants corresponding to putative homozygotes and triple-banded variants corresponding to putative heterozygotes for the case of a dimeric enzyme) and from the observation that putative genotype distributions correspond approximately to Hardy-Weinberg expectations (Gömöry, 2000). Alleles were designated by their relative migration rate as related to the most frequent one. Unfortunately, due to transport distances and

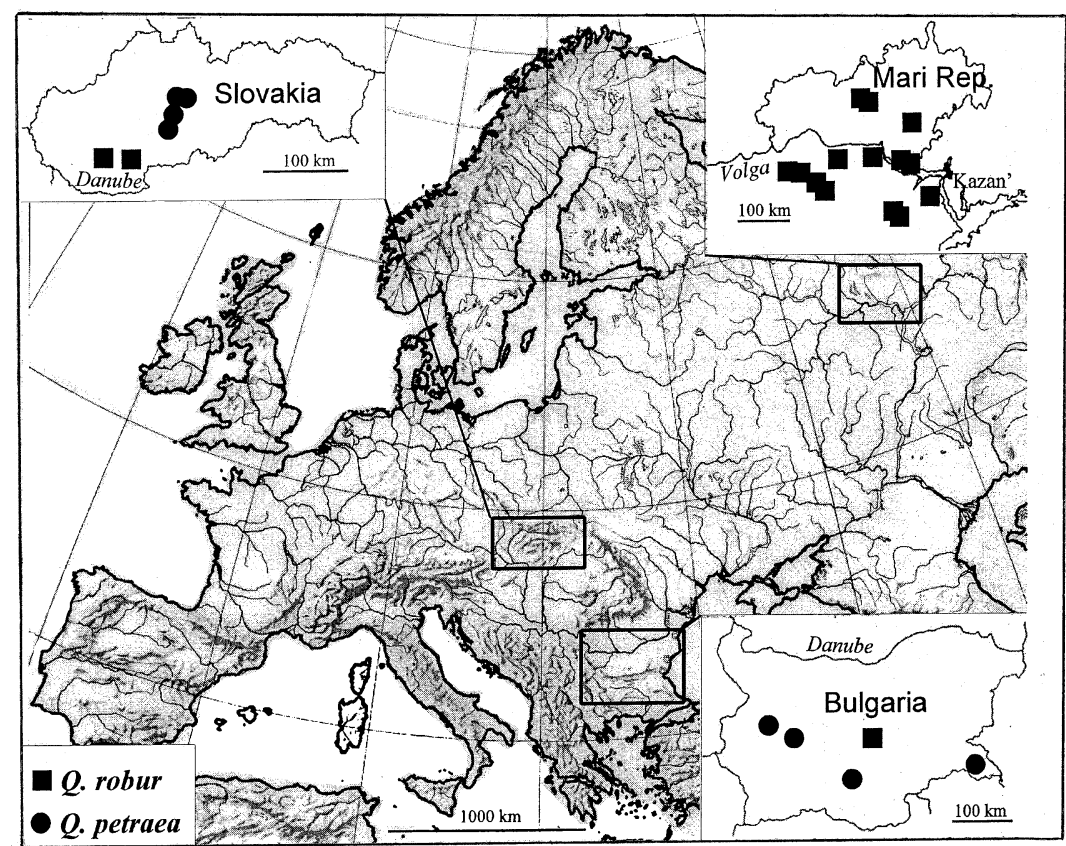

Fig. 1 Location of the investigated oak populations.

(C) The Genetics Society of Great Britain, Heredity, 86, 557-563. 
drying-out of some samples, the locus Gludh-A could not be reliably scored in all populations and other enzyme systems that were tested failed to give interpretable zymograms.

Allelic frequencies at each locus were calculated based on diploid genotypes. Differences in allelic frequencies between populations, regions, and species, were tested using the probability test (Raymond \& Rousset, 1995). Expected Hardy-Weinberg heterozygosity and effective number of alleles were used to characterize the genetic diversity. Since there were big differences in sample sizes among the regions, mean number of alleles was not considered an appropriate measure of the genetic multiplicity. Therefore, we used the measure of allelic richness developed by Petit et al. (1998). Allelic richness $A[g]$ corresponds to the number of different alleles found when $g$ gene copies are sampled at the locus in question. Since $Q$. robur in the Bulgarian region was represented by only one population, where 40 trees were sampled, $g$ was set to 80 .

Genetic distances between populations were calculated following Nei (1978). Principal coordinate analysis (Gower, 1966) was used for the interpretation of the genetic distance matrix. The structure of gene diversity (as measured by expected heterozygosity) within the Q. robur $/ Q$. petraea complex was analysed by subdividing the total gene diversity $\left(H_{\mathrm{T}}\right)$ into four components: $H_{\mathrm{S}}$, the within-population diversity; $D_{\mathrm{SR}}$, diversity among populations within regions; $D_{\mathrm{RQ}}$, diversity among regions within species; and $D_{\mathrm{QT}}$, diversity among species within the complex, following Nei (1973).

\section{Results}

\section{Genetic diversity}

Mean number of alleles per locus ranged between 1.8 and 2.6 in pedunculate oak populations and from 2.0 to 3.0 in sessile oak populations, this measure is very sensitive to sample size, and so must be regarded with caution. However, allelic richness (referring to equal sample sizes) indicates the same pattern; slightly higher levels of genetic multiplicity in $Q$. petraea compared to Q. robur (Table 1). On the other hand, diversity levels, as measured by both effective number of alleles and expected heterozygosity, are slightly higher in $Q$. robur compared to $Q$. petraea. There does not seem to be an association between allelic richness and diversity at the regional level, it may even seem to be negative; the Bulgarian pedunculate oak population possesses the smallest number of alleles, but, at the same time, exhibits the highest diversity level. However, this opposite trend was not confirmed at the population level, where a positive correlation between allelic richness and diversity was found: $r=0.47^{*}$ and $r=0.61^{* *}$ for $n_{e}$ and $H_{E}$, respectively $(* P \leq 0.05 ; * * P \leq 0.01)$.

\section{Amounts and patterns of genetic differentiation}

Except for $I d h-B / 140$, no allele proved to be speciesspecific in the sense that it occurred in all populations (or at least all regions) of one species and was absent in the other species. Some alleles appear to be regionspecific (Gludh-A/133, Got-B/80,70), but almost all these alleles are extremely rare (Table 2 ). There are, however, significant differences in allele frequencies between the species, as well as among populations within both pedunculate and sessile oaks. Except for $M d h-D$, the interspecific differences are significant at all loci. However, there are only two loci within the investigated set, where the differences are apparent and concern frequent alleles (with a frequency over 0.05 ); Idh-B and Gludh- $A$. Unfortunately, Gludh-A is the locus that could not be scored in all populations.

Specifically, Gludh- $A$ proved to differentiate the species. Therefore, we made most calculations for those loci which could reliably be scored in all populations (Fest-A, Mnr-A, Mdh-D, Idh-B, Skdh-A, Got-B, Pgi-B),

Table 1 Characteristics of genetic diversity in the investigated oak species and regions

\begin{tabular}{lcccccccc}
\hline Species & Region & $N$ & $n_{\mathrm{a}}^{\dagger}$ & $A_{T}[80] \dagger$ & $A_{T}[80] \dagger$ & $n_{\mathrm{e}}^{\dagger}$ & $H_{\mathrm{E}} \dagger$ & $H_{\mathrm{O}} \dagger$ \\
\hline Q. robur & RU & $656.6 \pm 30.9$ & $4.1 \pm 0.7$ & 2.90 & 2.87 & $1.202 \pm 0.088$ & $0.163 \pm 0.053$ & $0.161 \pm 0.053$ \\
& SK & $100.5 \pm 0.3$ & $3.6 \pm 0.2$ & 2.72 & 2.68 & $1.186 \pm 0.107$ & $0.136 \pm 0.060$ & $0.122 \pm 0.051$ \\
& BG & $40.0 \pm 0.0$ & $2.6 \pm 0.4$ & 2.60 & - & $1.224 \pm 0.118$ & $0.166 \pm 0.066$ & $0.179 \pm 0.072$ \\
Q. petraea & SK & $189.6 \pm 2.6$ & $4.6 \pm 0.8$ & 3.23 & 3.32 & $1.164 \pm 0.044$ & $0.150 \pm 0.033$ & $0.139 \pm 0.030$ \\
& BG & $158.8 \pm 19.0$ & $3.7 \pm 0.7$ & 2.80 & 2.70 & $1.119 \pm 0.044$ & $0.112 \pm 0.035$ & $0.101 \pm 0.037$ \\
\hline
\end{tabular}

Standard errors are given for $N, n_{\mathrm{a}}, n_{\mathrm{e}}, H_{\mathrm{E}}$, and $H_{\mathrm{O}}$.

$N$, mean sample size per locus; $n_{\mathrm{a}}$, mean number of alleles per locus; $A_{\mathrm{T}}$, allelic richness; $n_{\mathrm{e}}$, effective number of alleles; $H_{\mathrm{E}}$, expected heterozygosity; $H_{\mathrm{O}}$, observed heterozygosity.

RU, Russia; SK, Slovakia; BG, Bulgaria.

$\dagger$ Gludh- $A$ excluded.

$\$$ Gludh- $A$ included.

(C) The Genetics Society of Great Britain, Heredity, 86, 557-563. 
Table 2 Mean allelic frequencies in the investigated oak species and regions

\begin{tabular}{|c|c|c|c|c|c|c|c|c|c|}
\hline Locus & Allele $R_{\mathrm{m}}$ & \multicolumn{3}{|c|}{$Q$. robur } & $P \dagger$ & \multicolumn{2}{|c|}{$Q \cdot$ petraea } & $P \ddagger$ & $P \S$ \\
\hline \multirow{4}{*}{ Fest- $A$} & 120 & 0.000 & 0.000 & 0.000 & \multirow{4}{*}{0.000} & 0.000 & 0.012 & \multirow{4}{*}{0.000} & \multirow{4}{*}{0.000} \\
\hline & 115 & 0.059 & 0.060 & 0.050 & & 0.033 & 0.012 & & \\
\hline & 109 & 0.017 & 0.010 & 0.000 & & 0.046 & 0.002 & & \\
\hline & 70 & 0.000 & 0.000 & 0.063 & & 0.005 & 0.000 & & \\
\hline \multirow[t]{4}{*}{$M n r-A$} & 143 & 0.023 & 0.005 & 0.000 & \multirow[t]{4}{*}{0.000} & 0.003 & 0.002 & \multirow[t]{4}{*}{0.000} & \multirow[t]{4}{*}{0.000} \\
\hline & 127 & 0.022 & 0.020 & 0.000 & & 0.008 & 0.000 & & \\
\hline & 100 & 0.902 & 0.955 & 0.988 & & 0.922 & 0.861 & & \\
\hline & 88 & 0.004 & 0.000 & 0.000 & & 0.003 & 0.020 & & \\
\hline \multirow[t]{3}{*}{$M d h-D$} & 120 & 0.001 & 0.005 & 0.000 & \multirow[t]{3}{*}{0.361} & 0.000 & 0.000 & \multirow[t]{3}{*}{ NT } & \multirow[t]{3}{*}{ NT } \\
\hline & 100 & 0.999 & 0.985 & 1.000 & & 1.000 & 1.000 & & \\
\hline & 80 & 0.000 & 0.010 & 0.000 & & 0.000 & 0.000 & & \\
\hline \multirow[t]{4}{*}{$I d h-B$} & 140 & 0.000 & 0.000 & 0.000 & \multirow[t]{4}{*}{0.112} & 0.047 & 0.010 & \multirow[t]{4}{*}{0.000} & 0.000 \\
\hline & 123 & 0.320 & 0.391 & 0.475 & & 0.081 & 0.036 & & \\
\hline & 100 & 0.680 & 0.604 & 0.525 & & 0.867 & 0.948 & & \\
\hline & 60 & 0.000 & 0.005 & 0.000 & & 0.005 & 0.005 & & \\
\hline$S k d h-A$ & 109 & 0.003 & 0.000 & 0.000 & 0.000 & 0.003 & 0.000 & 0.034 & 0.000 \\
\hline & 106 & 0.035 & 0.000 & 0.000 & & 0.003 & 0.009 & & \\
\hline & 103 & 0.017 & 0.030 & 0.063 & & 0.019 & 0.000 & & \\
\hline & 70 & 0.000 & 0.000 & 0.038 & & 0.000 & 0.000 & & \\
\hline$P g i-B$ & 132 & 0.003 & 0.005 & 0.000 & 0.001 & 0.018 & 0.006 & 0.000 & 0.000 \\
\hline & 128 & 0.015 & 0.035 & 0.000 & & 0.066 & 0.042 & & \\
\hline & 118 & 0.001 & 0.000 & 0.000 & & 0.018 & 0.030 & & \\
\hline & 106 & 0.000 & 0.000 & 0.000 & & 0.003 & 0.000 & & \\
\hline & 100 & 0.981 & 0.950 & 0.962 & & 0.876 & 0.890 & & \\
\hline & 72 & 0.001 & 0.010 & 0.038 & & 0.020 & 0.033 & & \\
\hline Gludh-A & 133 & 0.000 & 0.000 & & 0.233 & 0.101 & 0.000 & 0.000 & 0.000 \\
\hline & 117 & 0.058 & 0.045 & & & 0.559 & 0.872 & & \\
\hline & 100 & 0.928 & 0.950 & & & 0.275 & 0.128 & & \\
\hline & 83 & 0.014 & 0.005 & & & 0.065 & 0.000 & & \\
\hline
\end{tabular}

$P$, probability test of differences in allelic frequencies: $P \dagger$, among populations of $Q$. robur, $P \ddagger$ among populations of $Q$. petraea, $P \S$, between pooled population sets of $Q$. robur and $Q$. petraea.

NT, not tested.

and subsequently with these loci plus Gludh- $A$ set for an incomplete population. As indicated by genetic distances (Table 3), if Gludh-A is excluded, the differentiation between species is smaller than within both pedunculate and sessile oaks. However, inclusion of Gludh-A enhances considerably the between-species distances, whereas 
Table 3 Average Nei's genetic distances between populations within and between species and regions (the diagonal and below) and the number of loci exhibiting significant differences $(P<0.05)$ in allelic frequencies between regions and species (above the diagonal)

\begin{tabular}{|c|c|c|c|c|c|c|}
\hline \multirow[b]{2}{*}{ Species } & \multirow[b]{2}{*}{ Region } & \multicolumn{3}{|c|}{ Q. robur } & \multicolumn{2}{|c|}{ Q. petraea } \\
\hline & & RU & SK & BG & SK & BG \\
\hline \multirow[t]{3}{*}{ Q. robur } & RU & $0.002(0.001)$ & $6(6)$ & $5(-)$ & $6(7)$ & $6(7)$ \\
\hline & SK & $0.003(0.004)$ & $0.003(0.003)$ & $3(-)$ & $4(5)$ & $5(6)$ \\
\hline & BG & $0.005(-)$ & $0.002(-)$ & $-(-)$ & $4(-)$ & $5(-)$ \\
\hline \multirow[t]{2}{*}{ Q. petraea } & SK & $0.010(0.070)$ & $0.015(0.078)$ & $0.021(-)$ & $0.003(0.008)$ & $4(5)$ \\
\hline & BG & $0.013(0.091)$ & $0.015(0.099)$ & $0.026(-)$ & $0.005(0.011)$ & $0.004(0.005)$ \\
\hline
\end{tabular}

Values for all loci excluding Gludh- $A$. The values in parentheses include Gludh- $A$. Region abbreviation as in Table 1.

the differentiation within pedunculate oak is almost unaffected and the distances within the sessile oak population set increase only slightly.

As usual in forest trees, the major proportion of the gene diversity (over 90\%) is harboured within populations for almost all loci. The surprising observation is that in general, the component of diversity among populations within regions is higher than the component among regions within species. For such small and geographically distant regions, the opposite would be expected. The interspecific component exceeds 5\% only in one case $(I d h-B)$. The only locus deviating from this general picture is Gludh-A. Almost half of the variation at this locus can be attributed to the variation between species, and there are considerable differences among regions as well, mainly in $Q$. petraea.

Multilocus patterns of the genetic differentiation were expressed by genetic distances. Even when the Gludh-A locus is excluded, both oak species are quite clearly differentiated (Fig. 2a). There are some outliers, but the point fields representing both species are separated. When Gludh- $A$ is taken into account, the oak species are separated even more clearly (Fig. 2b). However, in both cases, geographical trends are difficult to distinguish. Point fields of individual regions overlap considerably, mainly in $Q$. robur.

\section{Discussion}

The levels of genetic multiplicity found in our study roughly correspond to those reported by previous studies, which range from 2.5 to 3.2 for comparable sample sizes and comparable sets of isozyme loci (Müller-Starck \& Ziehe, 1991; Zanetto et al., 1994). On the other hand, diversity values are generally lower by $15-20 \%$ in respect of the effective number of alleles and more than $50 \%$ in respect of the expected heterozygosity. However, 10-20 loci is not a representative
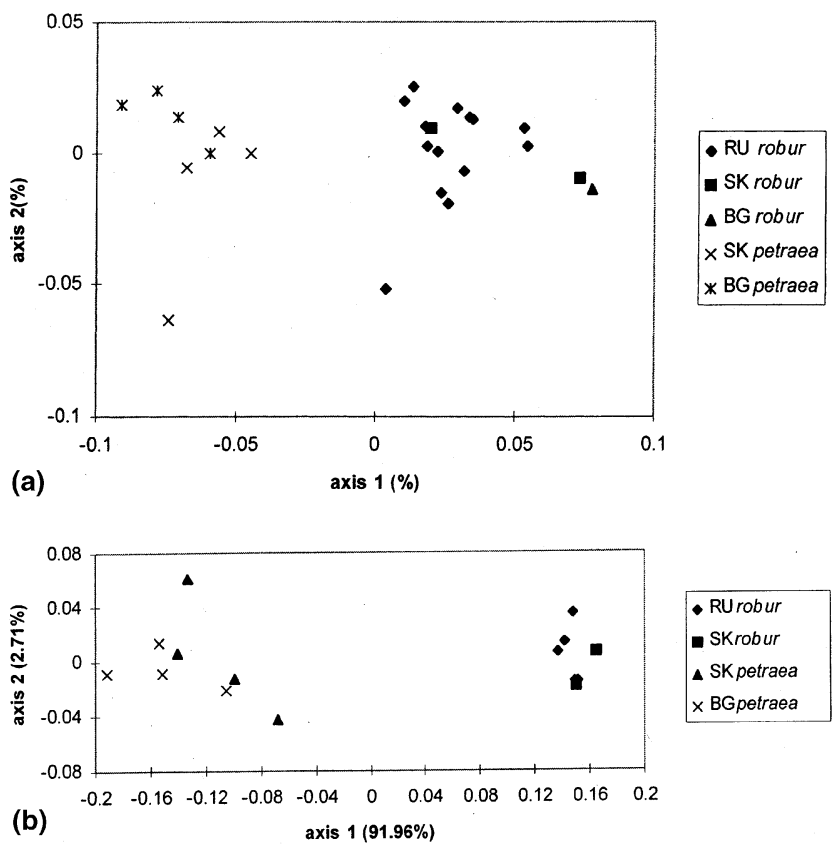

Fig. 2 (a) Scattergram of the principal coordinate analysis of Nei's genetic distances between oak populations; locus Gludh- $A$ excluded. (b) Scattergram of the principal coordinate analysis of Nei's genetic distances between oak populations; locus $G l u d h-A$ included.

random sample of the genome, so comparing average values of diversity characteristics based on different sets of markers is not very meaningful.

In spite of introgression occurring in mixed stands and the subsequent occurrence of intermediate forms, both species are morphologically and ecologically distinct (Aas, 1993). Taxonomists, as well as geneticists, dealing with European oaks almost all agree that $Q$. robur and $Q$. petraea should be considered separate species. On the other hand, the interspecific differentiation found within the $Q$. robur $/ Q$. petraea complex using nuclear as well as cytoplasmic markers is weak. 
Table 4 Gene diversity components in the $Q$. robur/ Q. petraea complex

\begin{tabular}{lcccc}
\hline Locus & $H_{\mathrm{S}}$ & $G_{\mathrm{SR}}$ & $G_{\mathrm{RQ}}$ & $G_{\mathrm{QT}}$ \\
\hline Fest- $A$ & 0.9407 & 0.0433 & 0.0094 & 0.0066 \\
Mnr- $A$ & 0.9709 & 0.0181 & 0.0038 & 0.0071 \\
Idh- $B$ & 0.9054 & 0.0095 & 0.0071 & 0.0780 \\
Mdh- $D$ & 0.9309 & 0.0245 & 0.0273 & 0.0173 \\
Skdh- $A$ & 0.9703 & 0.0226 & 0.0029 & 0.0041 \\
Got- $B$ & 0.9597 & 0.0249 & 0.0020 & 0.0134 \\
Pgi- $B$ & 0.9544 & 0.0222 & 0.0039 & 0.0194 \\
Gludh- $A$ & 0.4078 & 0.0237 & 0.1016 & 0.4669 \\
Mean $\dagger$ & 0.9475 & 0.0236 & 0.0081 & 0.0208 \\
Mean $\dagger$ & 0.8014 & 0.0189 & 0.0341 & 0.1456 \\
\hline
\end{tabular}

$H_{\mathrm{S}}$, within-population diversity; $G_{\mathrm{SR}}$, diversity among populations within regions; $G_{\mathrm{RQ}}$, diversity among regions within species; $G_{\mathrm{QT}}$, diversity among species within the complex (proportions of the total gene diversity $H_{\mathrm{T}}$ ).

$\dagger$ Without Gludh-A; \$including Gludh- $A$.

Genetic distances between populations of different species are generally almost twice as high as within species (Müller-Starck et al., 1993; Zanetto et al., 1994), but a greater difference between intraspecific and interspecific genetic distances could be expected.

For most European tree species, the differentiation patterns are closely associated with the history of the postglacial recolonization. Three main refugia of oaks are supposed to have existed during the last (Würm/ Weichsel) glaciation; these were located on the Iberian, Apennine, and Balkan peninsulas. Dumolin-Lapègue et al. (1997) support the hypothetical existence of a fourth oak refugium in the Caucasus. Russian authors even consider the possibility of oak refugia in the hills and mountains east of the Volga river (Obshchij Syrt, Southern Urals) (Denisov, 1980). Among the populations investigated within this study, only the origin of the Bulgarian ones is unambiguous, since they are situated near the putative Balkan refugium. DumolinLapègue et al. (1997) consider the immigration of oak to Russia both from the Balkans and the controversial Caucasus refugium possible. A similar situation applies to Slovak populations; haplotypes of both Apennine and Balkan origins were found in this region. Despite a large geographical gap between Russian populations and the rest, genetic distances within the pedunculate oak population set were very small and did not exhibit any geographical pattern. In sessile oak, genetic distances within both Slovak and Bulgarian regions were small and comparable to distances between regions (except for Gludh-A). Such a lack of geographical patterning would support the hypothesis of a common origin from one refugium, i.e. results confirm neither the assumption of the immigration of Russian pedunculate oak from the Caucasus nor its origin from local refugia. However, the information value of isozyme markers in this respect is much lower than that of neutral maternally inherited cpDNA markers (Petit et al., 1997).

Among the loci we studied, only two exhibited high levels of interspecific differentiation: $I d h-B$ and $G l u d h-A$. The first locus exhibits consistent significant differences in allelic frequencies between species over the whole range (Schroeder, 1989; Müller-Starck et al., 1993; Zanetto et al., 1994). Such differences between oak species are rather the rule than the exception, although they are very rarely consistent over different geographical regions. A phosphoglucomutase locus seems to differentiate both species also. The difference in the frequencies of the most abundant allele varies between 0.2 and 0.5 (Herzog, 1996; Zanetto et al., 1994). Unfortunately, for Gludh-A, such information is not available. Slovakia is the sole region where this locus was analysed in both oak species. However, the magnitude of differentiation and a relative consistency of allelic profiles within species suggest that the observed differentiation at this locus is characteristic for sessile and pedunculate oaks. The coefficient of interspecific genetic differentiation, $G_{\mathrm{QT}}=47 \%$, at $G l u d h-A$ is very much higher than any value reported for this pair of species. Nevertheless, no species-specific alleles were found. Further analyses in the other parts of the oak range would be necessary before using this as a diagnostic locus.

\section{Acknowledgements}

Technical assistance of Mrs. Zuzana Slančíková is gratefully acknowledged. This study was supported by research grants nos $1 / 7056 / 20$ and $1 / 4036 / 97$ from the Slovak Grant Agency for Science.

\section{References}

AAs, G. 1993. Taxonomical impact of morphological variation in Quercus robur and Quercus petraea: a contribution to the hybrid controversy. Ann. Sci. For., 50, 107-113.

BARRENECHE, T., BAHRMAN, N. AND KREMER, A. 1996. Two dimensional gel electrophoresis confirms the low level of genetic differentiation between Quercus robur L. and Quercus petraea (Matt.) Liebl. Forest Genet., 3, 89-92.

BODÉNĖs, C., JOANDET, S., LAIGRET, F. AND KREMER, A. 1997. Detection of genomic regions differentiating two closely related oak species Quercus petraea (Matt.) Liebl. and Quercus robur L. Heredity, 78, 433-444.

BORDÁCS, S. AND BURG, K. 1997. Genetic differentiation by RAPD-markers of oak species in Hungary. In: Steiner, K. C. (ed.) Diversity and Adaptation in Oak Species, pp. 121-131. The Pennsylvania State University, Pennsylvania. 
DENISOV, A. K. 1980. Postglacial dynamics of the Northern border of the English oak range in the USSR and phylogeny of oak forests in the North. Lesovedenie, 21, 3-11.

DUMOLIN-LAPÈGUE, S., DEMESURE, B., FINESCHI, S., LE CORRE, V. ET AL. 1997. Phylogeographic structure of white oaks throughout the European continent. Genetics, 146, 1475-1487.

GÖMÖRY, D. 2000. A gene coding for a non-specific NADdependent dehydrogenase shows a strong differentiation between Quercus robur and Quercus petraea. Forest Genet., 7, 167-170.

GOWER, J. C. 1966. Some distance properties of latent root and vector methods used in multivariate analysis. Biometrika, 53, 325-338.

HERzOG, s. 1996. Genetic inventory of European oak populations: consequences for breeding and gene conservation. Ann. Sci. For., 53, 783-793.

KLEINSCHMIT, J. R. G., KREMER, A. AND ROLOFF, A. 1995. Sind Stieleiche und Traubeneiche zwei getrennte Arten? AFZ/Der Wald, 26, 1453-1456.

LINNAEUS, C. 1753. Species Plantarum, 2. Stockholm.

LONGAUER, R. 1996. Genetic Diversity of Silver Fir (Abies alba Mill.). PhD Thesis, Technical University in Zvolen, Zvolen.

MOREAU, F., KLEINSCHMit, J. AND KREMER, A. 1994. Molecular differentiation between $Q$. petraea and $Q$. robur assessed by random amplified DNA fragments. Forest Genet., 1, 51-64.

MUiR, G., FLEMING, C. C. AND SCHLÖtTERER, C. 2000. Species status of hybridizing oaks. Nature, 405, 1016.

MÜLLER-STARCK, G. AND ZIEHE, M. 1991. Genetic variation in populations of Fagus sylvatica L., Quercus robur L. and Quercus petraea (Matt.) Liebl. in Germany. In: MüllerStarck, G. and Ziehe, M. (eds) Genetic Variation in European Populations of Forest Trees, pp. 125-139. Sauerländer's Verlag, Frankfurt am Main.

MÜLlER-STARCK, G., HERZOG, S. AND HATTEMER, H. H. 1993. Intra- and interpopulational genetic variation in juvenile populations of Quercus robur L. and Quercus petraea Liebl. Ann. Sci. For., 50, 233-244.

MÜLLER-STARCK, G., ZANETTO, A., KREMER, A. AND HERZOG, S. 1996. Inheritance of isoenzymes in sessile oak (Quercus petraea (Matt.) Liebl.) and offspring from interspecific crosses. Forest Genet., 3, 1-12.

NEI, M. 1973. Analysis of gene diversity in subdivided populations. Proc. Natl. Acad. Sci. U.S.A., 70, 3321-3323.

NEI, M. 1978. Estimation of average heterozygosity and genetic distance from a small number of individuals. Genetics $\mathbf{8 9}$, 583-590.

PETIT, R. J., WAGNER, D. B. AND KREMER, A. 1993. Ribosomal DNA and chloroplast DNA polymorphisms in a mixed stand of Quercus robur and Quercus petraea. Ann. Sci. For., 50, 41-47.

PETIT, R. J., PINEAU, E., DEMESURE, B., BACILIERI, R. ET AL. 1997. Chloroplast DNA footprints of postglacial recolonization by oaks. Proc. Natl. Acad. Sci. U.S.A., 94, 9996-10001.

PETIT, R. J., EL MOUSADIK, A. AND PONS, O. 1998. Identifying populations for conservation on the basis of genetic markers. Cons. Biol., 12, 844-855.

RAYMOND, M. AND ROUSSET, F. 1995. An exact test of population differentiation. Evolution, 49, 1280-1283.

SCHROEDER, S. 1989. Artunterscheidung bei Eiche auf Grund von Isoenzym-Markern. Allg. Forst- u. J.-Ztg., $\mathbf{1 6 0}$, 104-106.

schwarz, O. 1964. Quercus L. In: Tutin, T. G., Heywood, V. H., Burges, N. A., Valentine, D. H., Walters, S. M. and Webb, D. A. (eds) Flora Europaea, vol. 1: Lycopodiaceae to Platanaceae, pp. 61-64. Cambridge University Press, Cambridge.

STEINHOFF, S. 1997. Results of Quercus hybridization work from 1989 to 1996 at Escherode (Quercus petraea (Matt.) Liebl. and Quercus robur L.). In: Steiner, K. C. (ed.) Diversity and Adaptation in Oak Species, pp. 156-164. The Pennsylvania State University, Pennsylvania.

ZANETTO, A., ROUSSEL, G. AND KREMER, A. 1994. Geographic variation of interspecific differentiation between Quercus robur L. and Quercus petraea (Matt.) Liebl. Forest Genet., 1, 111-123.

ZANETTO, A., KREMER, A., MÜLLER-STARCK, G. AND HATTEMER, H. H. 1996. Inheritance of isozymes in pedunculate oak (Quercus robur L.). J. Hered., 87, 364-370. 